\title{
Emissions from prescribed fires in temperate forest in south-east Australia: implications for carbon accounting
}

\author{
M. Possell ${ }^{1,2}$, M. Jenkins ${ }^{1}$, T. L. Bell ${ }^{1,2}$, and M. A. Adams ${ }^{1}$ \\ ${ }^{1}$ Faculty of Agriculture and Environment, University of Sydney, NSW 2006, Australia \\ ${ }^{2}$ Bushfire Cooperative Research Centre, 340 Albert Street, East Melbourne, VIC 3002, Australia \\ Correspondence to: M. Possell (malcolm.possell@sydney.edu.au)
}

Received: 23 April 2014 - Published in Biogeosciences Discuss.: 23 September 2014

Revised: 20 November 2014 - Accepted: 5 December 2014 - Published: 15 January 2015

\begin{abstract}
We estimated emissions of carbon, as equivalent $\mathrm{CO}_{2}\left(\mathrm{CO}_{2} \mathrm{e}\right)$, from planned fires in four sites in a southeastern Australian forest. Emission estimates were calculated using measurements of fuel load and carbon content of different fuel types, before and after burning, and determination of fuel-specific emission factors. Median estimates of emissions for the four sites ranged from 20 to $139 \mathrm{MgCO}_{2} \mathrm{e} \mathrm{ha}^{-1}$. Variability in estimates was a consequence of different burning efficiencies of each fuel type from the four sites. Higher emissions resulted from more fine fuel (twigs, decomposing matter, near-surface live and leaf litter) or coarse woody debris (CWD; > $25 \mathrm{~mm}$ diameter) being consumed. In order to assess the effect of declining information quantity and the inclusion of coarse woody debris when estimating emissions, Monte Carlo simulations were used to create seven scenarios where input parameters values were replaced by probability density functions. Calculation methods were (1) all measured data were constrained between measured maximum and minimum values for each variable; (2) as in (1) except the proportion of carbon within a fuel type was constrained between 0 and $1 ;$ (3) as in (2) but losses of mass caused by fire were replaced with burning efficiency factors constrained between 0 and 1; and (4) emissions were calculated using default values in the Australian National Greenhouse Accounts (NGA), National Inventory Report 2011, as appropriate for our sites. Effects of including CWD in calculations were assessed for calculation Method 1, 2 and 3 but not for Method 4 as the NGA does not consider this fuel type. Simulations demonstrate that the probability of estimating true median emissions declines strongly as the amount of information available declines. Including CWD in scenarios increased uncertainty in calculations because CWD is the most variable contributor to fuel
\end{abstract}

load. Inclusion of CWD in scenarios generally increased the amount of carbon lost. We discuss implications of these simulations and how emissions from prescribed burns in temperate Australian forests could be improved.

\section{Introduction}

Fire affects the carbon balance of terrestrial biomes by immediately releasing carbon dioxide $\left(\mathrm{CO}_{2}\right)$, carbon monoxide (CO), methane $\left(\mathrm{CH}_{4}\right)$, volatile organic compounds (VOCs) and particulate matter (PM) into the atmosphere through the consumption of fuel (e.g. Urbanski et al., 2009) and by modifying carbon stocks in post-fire vegetation. Immediate modification of carbon stocks results from combustion of fuels while post-fire changes are due to alteration in activity of microorganisms responsible for decomposition of organic matter and uptake of $\mathrm{CO}_{2}$ via photosynthesis by vegetation regrowth. Over the period 1997-2009, global fire emissions were estimated to contribute, on average, $2 \mathrm{Pg} \mathrm{C} \mathrm{yr}^{-1}$ to the atmosphere, with $15 \%$ of those emissions coming from extra-tropical fires (van der Werf et al., 2010). Australia contributes about $6.7 \%$ of the global fire emissions, the fourth largest contributor behind Africa (51.6\%), South America (14.5\%), and Equatorial Asia (9.5\%) (van der Werf et al., 2010). A recent study estimated that fires in Australia contribute $127 \mathrm{Tg} \mathrm{Cyr}^{-1}$ to the atmosphere, about $6 \%$ of the net primary productivity with the greatest contribution coming from fires in tropical and savanna bioclimatic regions (Haverd et al., 2013). In contrast, contributions from cool and warm temperate bioclimatic regions to total annual fire 
emissions were limited except during severe bushfire seasons (Haverd et al., 2013).

Emissions from fires are still widely estimated as products of fuel load, burning efficiency, area burnt and emission factors for gases and particles of interest (Seiler and Crutzen, 1980; Langmann et al., 2009). Uncertainties in any of these variables can lead to a wide range of estimates for different gases. In large part, these uncertainties are a function of burning efficiency and vegetation characteristics (e.g. Stropiana et al., 2010), and spatial and temporal scales of measurement (e.g. Urbanski et al., 2011). Techniques such as lidar are being used to improve estimates of fuel load (e.g. Loudermilk et al., 2009). Even so, fuel accumulation varies widely in space and time as a result of the interaction of many factors such as topography, soils, disturbance history (e.g. previous land use, insects, fire) and climate (e.g. due to variations in rainfall patterns; Bradstock, 2010); hence, remote sensing techniques will require intensive calibration. In Australia, estimates of emissions from forest fires are based on fine fuels (e.g. grass, leaves, bark and twigs) and tend to ignore fuel types such as coarse woody debris (CWD) or understorey fuels (Volkova and Weston, 2013). A more comprehensive set of fuel load measurements is required to develop reliable fuel load models.

A major source of uncertainty in estimates has been emission factors as they invariably contain large uncertainties (Andreae and Merlet, 2001; Akagi et al., 2011; Urbanski et al., 2011). Published emission factors for forests in southeast Australia are few. One study developed emission factors for a small set of gases directly using aircraft-based sampling (Hurst et al., 1996), while another used Fourier transform infrared spectroscopy at ground level (Paton-Walsh et al., 2014). Ground-based spectrometry or satellite-derived enhancement ratios have also been used to derive emission factors (Paton-Walsh et al., 2004, 2005; Young and PatonWalsh, 2011; Glatthor et al., 2013). These non-direct methods often use an emission factor for $\mathrm{CO}$ as a reference. However, that factor too is often assumed rather than measured. Compared to emission measurements made for savanna and grassland in Australia (e.g. Hurst et al., 1994a, b; PatonWalsh et al., 2010), emission factors from Australian temperate forests are usually aggregated for all fuel types and do not account for factors such as fire severity and patchiness (cf. Russell-Smith et al., 2009). There have been no studies of seasonal variation in emission factors in Australian forests nor any demonstration that such variation is minimal, as found for savanna in Australia for certain trace gases (Meyer et al., 2012).

Return frequencies of wildfires in extra-tropical (temperate) forests in Australia are typically longer than that of tropical grassland and savanna and are often decadal compared to annual and biannual (Bradstock, 2010; Adams, 2013). In addition, the total area of temperate forest burnt on an annual basis is considerably smaller (Russell-Smith et al., 2007), notwithstanding large single fire events (Adams,
2013). Planned or prescribed burning in temperate forests to mitigate risks to life and property from wildfires is used at moderate return frequencies (e.g. 7-10 years) (Penman et al., 2007; McCaw, 2013). Bennett et al. (2013) recently demonstrated that in a mixed species eucalypt forest, repeated prescribed burning at shorter intervals (e.g. 3-5 years) reduces tree-based carbon stocks. The generality of such findings requires further research, as does the fate of the carbon released during combustion. Among the few indirect analyses of emissions from temperate forests (based on changes in litter and biomass C), Volkova and Weston (2013) estimated that $6.7 \mathrm{MgC} \mathrm{ha}^{-1}$ was emitted to the atmosphere from prescribed burning in Eucalyptus obliqua forests in south-east Australia. However, there remains a general paucity of direct empirical data on emissions, and this impedes efforts to calibrate indirect estimates.

Here we present emission factors for different fuel types from a temperate Eucalyptus forest in south-east Australia and use these in conjunction with measurements of fuel load and carbon content to estimate emissions from this forest type. We compare our estimates to those made using more restricted data sets and based upon the methodology described in the Australian National Greenhouse Gas Inventory Report 2011 (DIICCSRTEE, 2013) and discuss the merits of the different approaches.

\section{Materials and methods}

\subsection{Study sites}

The general study area was located in East Gippsland, Victoria, Australia $\left(37^{\circ} 42^{\prime} 0^{\prime \prime} \mathrm{S}, 148^{\circ} 27^{\prime} 0^{\prime \prime} \mathrm{E}\right)$. The elevation of study sites range from 56 to $124 \mathrm{~m}$ above sea level, and the study area has an average annual precipitation of $850 \mathrm{~mm}$. Sites were selected using the Victorian Department of Environment and Primary Industries (DEPI; Victoria, Australia) fire operations plans for the area. Three sites west of Orbost were burnt in planned fires in 2011 and one site east of Orbost was burnt in a planned fire in 2012. The selected sites were named according to the nearest crossroad or location: Oliver, Pettmans, South Boundary and Upper Tambo. All sites are classified as Lowland Forest (Ecological Vegetation Class 16; Victoria Department of Sustainability and Environment, 2004). Sites varied in overstorey tree species composition although all were dominated by Yellow Stringybark (Eucalyptus muelleriana A. W. Howitt), White Stringybark (E. globoidea Blakely) or Yertchuk (E. consideniana Maiden). The understorey vegetation in the western sites (Pettmans, South Boundary and Upper Tambo) is dominated by Sunshine Wattle (Acacia terminalis (Salisb.) J. F. Macbr.), Black Wattle (A. mearnsii De Wild.) and Burgen (Kunzea ericoides (A. Rich.) Joy Thomps.) with Bracken (Pteridium esculentum (G. Forst.) Cockayne) as the most common groundcover species. The eastern site (Oliver) was selected 
primarily because the understorey composition differed from the western sites. Here the understorey is dominated by Forest Geebung (Persoonia silvatica L. A. S. Johnson) and Sunshine Wattle (A. terminalis) with Wire Grass (Tetrarrhena juncea $\mathrm{R}$. Br.) as groundcover. Soils at all sites were formed on Pliocene (2-5 Ma) sands and gravels (Hendrickx et al., 1996; Van den Berg et al., 1996).

\subsection{Sampling protocol}

\subsubsection{Overstorey and understorey biomass}

Within each study site, three permanent circular plots were established at least $500 \mathrm{~m}$ apart within similar vegetation types. Due to the small elevation change of the general study area, all study sites had similar slope and aspect. Plots were located close to the road (20-50 m) to ensure they were burnt during the planned fire and were circular in shape $(22.5 \mathrm{~m}$ radius; $1590.4 \mathrm{~m}^{2}$ ). A schematic of the plot and sampling design is shown in Fig. 1. All pre-fire data were collected 1-3 months prior to the planned burning and post-fire data were collected within 1 month of burning. Diameter at breast height over bark (DBHOB; $1.3 \mathrm{~m}$ ) and number of individuals of trees in two size classes ( $\geq 2 \mathrm{~cm}$ to $<20 \mathrm{~cm} ; \geq 20 \mathrm{~cm}$ ) were measured for all overstorey (whole plot) and understorey tree species found in four circular subplots (radius $=5 \mathrm{~m}$ ) located $5 \mathrm{~m}$ along the north-south and east-west axes of each of the larger plots, as measured from the centre point. At least six trees per plot were measured for tree height to provide a representative stand height.

To determine aboveground biomass and carbon stocks represented by overstorey and understorey trees (equivalent to overstorey and intermediate tree canopy fuel layers, respectively in Gould et al., 2011), understorey allometric equations were developed for Yellow Stringybark (E. muelleriana; $n=10$ individuals harvested) and Silver Wattle (Acacia mearnsii; $n=11$ individuals harvested) using destructive harvesting. When species-specific allometric equations were not available or could not be developed by destructive sampling (i.e. overstorey), equations from Bi et al. (2004) for the species with the most similar size and growth form were used instead. Tree diameter and density were measured before planned burning. Data for overstorey species of Eucalyptus were pooled to represent a single biomass component (hereafter referred to as "Overstorey"), and data for all other tree species were pooled to form a second biomass component (hereafter referred to as "Understorey").

Ground layer vegetation (ground cover of grasses and Bracken; equivalent to the near-surface live fuel layer in Gould et al., 2011) together with any scattered small shrubs (equivalent to the elevated fuel layer in Gould et al., 2011), was collected by pruning at ground level four $1 \mathrm{~m}^{2}$ quadrats, each located $17.5 \mathrm{~m}$ along the north-south and east-west axes of each plot, as measured from the centre point. Samples were dried to constant weight at $70^{\circ} \mathrm{C}$ and subsamples were

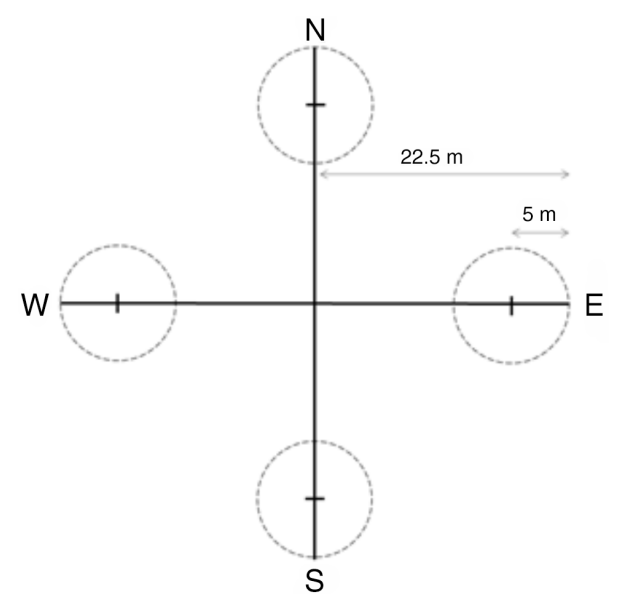

Figure 1. Plot layout for data and sample collection.

ground and analysed for total carbon content (\% dry weight) by combustion analysis (Elementar Vario Max CNS, Analysensysteme GmbH, Hanau, Germany). The mass of ground layer vegetation, twigs and litter (see below) remaining after prescribed burning was measured in the same way using quadrats positioned $2-3 \mathrm{~m}$ from the position of the original quadrat to avoid the influence of biomass removal prior to prescribed burning.

\subsubsection{Litter and coarse woody debris}

Litter on the forest floor $(<25 \mathrm{~mm}$ diameter; equivalent to the surface fuel layer in Gould et al., 2011) was collected from the same quadrats used for sampling near-surface live biomass. Samples were carefully collected from the soil surface to avoid contamination from the underlying mineral soil. Samples were dried to constant weight at $70^{\circ} \mathrm{C}$, weighed and sorted into size fractions. Fractions included plant material that was $<10 \mathrm{~mm}$ diameter (hereafter referred to as "Decomposing litter"); twigs, wood and bark that was $10-25 \mathrm{~mm}$ diameter (hereafter referred to as "Twigs"), and partial or whole leaves between 10 and $25 \mathrm{~mm}$ diameter (hereafter referred to as "Leaf litter"). Samples were collected pre- and post-fire, dried at $70^{\circ} \mathrm{C}$ to constant weight, and subsamples of the pre-fire fraction were ground and analysed for total carbon content (\% dry weight) by combustion analysis (Elementar Vario Max CNS, Analysensysteme GmbH, Hanau, Germany).

The volume of CWD was determined using the line intersect method (Van Wagner, 1968), where the north-south and east-west axes of each plot were used as transects (45 $\mathrm{m}$ each). The diameter, length and state of decomposition (sound or rotten) of all pieces of CWD (>25 mm diameter) intersecting each transect was measured. Subsamples of sound and rotten CWD were used to determine specific gravity (Ilic et al., 2000) and dried pre-fire subsamples ground and analysed for total carbon content (\% dry weight) 
by combustion analysis (Elementar Vario Max CNS, Analysensysteme GmbH, Hanau, Germany). The volume of CWD was determined before and after planned burning.

\subsection{Combustion analysis}

A ventilation-controlled Mass Loss Calorimeter (MLC; Fire Testing and Technology, East Grinstead, UK) with a porous holder was used for the combustion analysis. The MLC consisted of a conical heater and a load cell to measure the change in mass of a sample over time. The cone heater and load cell were contained within a stainless-steel enclosure, which was supplied with compressed air at a known flow rate of $140 \mathrm{~L} \mathrm{~min}^{-1}$. A $90 \mathrm{~cm}$ tall, $12 \mathrm{~cm}$ diameter stainlesssteel chimney on top of the enclosure contained a gas sampling ring probe mounted $60 \mathrm{~cm}$ above the enclosure. Air was drawn through the gas sampling ring at $2 \mathrm{~L} \mathrm{~min}^{-1}$ into a stainless-steel housing (Model H130; Headline Filters, Aylesford, UK) containing a silica-bonded borosilicate glass microfibre filter (Headline Filters, Aylesford, UK) and heated to $200^{\circ} \mathrm{C}$ to remove PM from the airstream. Air movement continued from the heated filter via a heated line $\left(200^{\circ} \mathrm{C}\right)$ into a sampling manifold. Air in the sampling manifold was diluted with ambient air, filtered through a $1 \mu \mathrm{m}$ PTFE filter (Pall Australia Pty. Ltd., Cheltenham, Australia) and pumped into the manifold to ensure that gas concentrations in the manifold were within the linear range of the various analysers used. Flow rates from the sample and dilution line were controlled by mass flow controllers (Aalborg, Orangeburg, US). The air temperatures in the manifold and stainless-steel chimney were measured at $1 \mathrm{~Hz}$ using type $\mathrm{K}$ thermocouples connected to a digital acquisition board (Model NI USB9211A; National Instruments, Sydney, Australia).

Mixing ratios of $\mathrm{CO}_{2}$ and $\mathrm{CO}$ were measured at $1 \mathrm{~Hz}$ using non-dispersive infrared gas analysers (Models 410i and 48i; Thermo Fisher Scientific Australia Pty. Ltd., Melbourne, Australia) and were calibrated using high purity $\mathrm{CO}_{2}$ or $\mathrm{CO}$ diluted in zero air (BOC Ltd., North Ryde, Australia).

In the MLC, a sample holder $(10 \times 10 \times 3 \mathrm{~cm})$ with a porosity of $27 \%$ was used to allow diffusion of air through the samples. For all material, samples were trimmed to fit the holder to uniformly fill the sample holder so that the sample thickness was maintained at approximately $3 \mathrm{~cm}$. The mass of the samples was recorded before burning and the mass of the residue after burning. The bulk density of the sample $\left(\mathrm{kg} \mathrm{m}^{-3}\right)$ was calculated as the initial sample mass divided by the volume of the sample holder. The moisture content (MC) of combusted samples (dry weight basis), determined by drying at $70^{\circ} \mathrm{C}$ until constant weight, ranged between 2 and $14 \%$. Samples were combusted in triplicate at an irradiance of $25 \mathrm{~kW} \mathrm{~m}^{-2}$ and a $10 \mathrm{kV}$ spark igniter was used to provide piloted ignition. A schematic of the equipment used for the combustion analysis is provided in Fig. 1 in the Supplement.

\subsection{Emission factors}

Emission factors for the gas species $\mathrm{CO}_{2}\left(\mathrm{EFCO}_{2}\right)$ and $\mathrm{CO}$ (EFCO) from each fuel (biomass) type were calculated in $\mathrm{g} \mathrm{kg}^{-1}$ dry fuel burnt. The mass of $\mathrm{CO}_{2}$ or $\mathrm{CO}$ released was calculated by summing products of excess $\mathrm{CO}_{2}$ or $\mathrm{CO}$ concentrations and flow rate measured at each time step for the duration of the burn.

Using the carbon mass balance method approach described by Radke et al. (1988) and outlined in Hurst et al. (1994b), emission factors for each fuel type were also expressed relative to elemental carbon content of dry fuels $\left(\mathrm{g} \mathrm{CgC}^{-1}\right)$. The $\mathrm{EFCO}_{2}$ was calculated from the fraction of total fuel carbon released to the atmosphere during combustion and $\mathrm{CO}_{2}$-normalised emission ratios of $\mathrm{CO}, \mathrm{CH}_{4}$, volatile organic compounds (VOC) and $\mathrm{PM} . \mathrm{EFCO}_{2}$ was calculated as

$$
\begin{aligned}
& \mathrm{EFCO}_{2}=\frac{\Delta \mathrm{CO}_{2}}{\mathrm{C}_{\text {fuel }}}= \\
& \frac{\frac{\Sigma \mathrm{C}_{\text {emit }}}{\mathrm{C}_{\text {fuel }}}}{1+\frac{\Delta \mathrm{CO}}{\Delta \mathrm{CO}_{2}}+\frac{\Delta \mathrm{CH}_{4}}{\Delta \mathrm{CO}_{2}}+\frac{\Delta \Sigma \mathrm{VOC}}{\Delta \mathrm{CO}_{2}}+\frac{\Delta \mathrm{PM}}{\Delta \mathrm{CO}_{2}}},
\end{aligned}
$$

where $\Sigma \mathrm{C}_{\text {emit }}$ is the mass of carbon released to the atmosphere during burning and $\mathrm{C}_{\text {fuel }}$ is the initial carbon content of the fuel. Therefore, $\Sigma \mathrm{C}_{\text {emit }} / \mathrm{C}_{\text {fuel }}$ represents the fraction of fuel carbon that is burnt and released to the atmosphere during combustion. $\Delta$ represents the excess molar mixing ratio of a species $\left(\mathrm{CO}_{2}, \mathrm{CO}, \mathrm{CH} 4, \Sigma \mathrm{VOC}\right.$ and $\left.\mathrm{PM}\right)$ over the background (the difference between its mixing ratios in smoke and clean air) (Hurst et al., 1994b). Emission factors $\left(\mathrm{g} \mathrm{Cg} \mathrm{C}^{-1}\right)$ for carbon-based species other than $\mathrm{CO}_{2}$ were calculated as

$\mathrm{EF}_{x}=\frac{\Delta X}{\Delta \mathrm{CO}_{2}} \times n \times \mathrm{EFCO}_{2}$,

where $\Delta X$ is the excess mixing ratio of species $X(\mathrm{CO}, \mathrm{CH} 4$, $\Sigma$ VOC or PM) and $n$ is the number of carbon atoms per molecule of species $X$. By definition, the sum of the emission factors for the carbon gases and PM, when measured on a g $\mathrm{C} \mathrm{g} \mathrm{C}^{-1}$ basis, will equal $\Sigma \mathrm{C}_{\text {emit }} / \mathrm{C}_{\text {fuel }}$.

Emission factors measured relative to elemental carbon content can be converted to emission factors ( $\mathrm{g} \mathrm{kg}^{-1}$ dry fuel) using Eq. (3):

$$
\mathrm{EF}_{x}\left[\mathrm{~g} \mathrm{X} \mathrm{kg}^{-1} \text { fuel }\right]=\frac{\mathrm{EF}_{x}\left[\mathrm{gC} \mathrm{g} \mathrm{C}^{-1}\right] \cdot \mathrm{C}_{\text {fuel }}}{\left(12 / \mathrm{Mw}_{x}\right)} \times 1000
$$

where $\mathrm{Mw}_{x}$ is the molecular weight $\left(\mathrm{g} \mathrm{mol}^{-1}\right)$ of chemical species $X$ and 12 is the molecular weight of carbon.

In this study, $\mathrm{CH}_{4}$, VOC and PM concentrations were not measured and hence the $\mathrm{CO}_{2}$-normalised emission ratios of these compounds are not available for the direct calculation of EFCO2 according to Eq. (1). Using $\mathrm{EFCO}_{2}\left(\mathrm{~g} \mathrm{CO}_{2} \mathrm{~kg}^{-1}\right)$, 
$\mathrm{EFCO}_{2}\left(\mathrm{~g} \mathrm{Cg} \mathrm{C}^{-1}\right)$ was solved for each fuel type by rearranging Eq. (3). This allowed for calculation of EFCO ( $\mathrm{g} \mathrm{Cg} \mathrm{C}^{-1}$ ) using Eq. (2) and known $[\mathrm{CO}] /\left[\mathrm{CO}_{2}\right]$ ratios. As the sum of emission factors for carbon gases and PM, when measured on a $\mathrm{g} \mathrm{CgC}^{-1}$ basis, will equal $\Sigma \mathrm{C}_{\mathrm{emit}} / \mathrm{C}_{\text {fuel }}$, $\mathrm{CH}_{4}$, VOC and PM were treated as pooled species $\left(\Sigma\left(\mathrm{CH}_{4}\right.\right.$, VOC, PM)). $\Sigma \mathrm{C}_{\mathrm{emit}} / \mathrm{C}_{\text {fuel }}$ ratios were measured for each fuel fraction by subtracting the mass of carbon remaining in the ash after combustion from the amount of carbon measured before combustion. The excess $\Sigma\left(\mathrm{CH}_{4}, \mathrm{VOC}, \mathrm{PM}\right)$ to excess $\mathrm{CO}_{2}$ ratio was then solved through optimisation (MS Excel v.14; Microsoft Corporation, Redmond, US) in order to make the sum of $\mathrm{EFCO}_{2}, \mathrm{EFCO}$ and $\mathrm{EF} \Sigma\left(\mathrm{CH}_{4}, \mathrm{VOC}\right.$, $\mathrm{PM})$ equal to the measured $\Sigma \mathrm{C}_{\mathrm{emit}} / \mathrm{C}_{\text {fuel }}$. This method assumes that the value of $n$ used in Eq. (2) in order to calculate $\mathrm{EF} \Sigma\left(\mathrm{CH}_{4}, \mathrm{VOC}, \mathrm{PM}\right)$ is equal to 1 .

\subsection{Emission calculations}

Emissions, in terms of equivalent $\mathrm{CO}_{2}\left(E_{j} ; \mathrm{MgCO}_{2} \mathrm{e} \mathrm{ha}^{-1}\right)$, from each plot at each site $(j)$ were calculated as the sum of the emissions from each fuel (biomass) class $(k)$ for each carbon species $(x)$ :

$E_{j}=\sum_{x k} \mathrm{EF}_{x j k}\left(\mathrm{C}_{\text {fuel }_{j k}} \times\left(m_{\text {pre }_{j k}}-m_{\text {post }_{j k}}\right)\right) \times 3.66$,

where $m_{\text {pre }}$ and $m_{\text {post }}$ are the fuel loads $\left(\mathrm{Mg} \mathrm{ha}^{-1}\right)$ before and after burning and 3.66 is a conversion factor from $\mathrm{C}$ to $\mathrm{CO}_{2}$. $\mathrm{C}_{\text {fuel }}$ for CWD was assumed to equal that measured from twigs ( $<25 \mathrm{~mm}$ diameter).

Emissions can also be calculated using Eq. (4) but by substituting $m_{\text {pre }}-m_{\text {post }}$ with the product of the pre-fire fuel load and a burning efficiency factor (BEF).

$E_{j}=\sum_{x k} \mathrm{EF}_{x j k}\left(\mathrm{C}_{\text {fuel }_{j k}} \times m_{\text {pre }_{j k}} \times \mathrm{BEF}_{j k}\right) \times 3.66$

The BEF is defined as the mass of fuel that is exposed to fire that is pyrolysed (Russell-Smith et al., 2009). It is determined from the mass of fuel $\left(m_{\text {pre }}\right)$ before combustion and the mass of the unburnt fuel residue and ash remaining after combustion $\left(m_{\text {post }}\right)$ :

$\mathrm{BEF}=1-\frac{m_{\text {post }}}{m_{\text {pre }}}$

Eq. (5) was used to calculate emission estimates for the sites as described in the Australian National Greenhouse Gas Inventory Report 2011 (AUSNIR; DIICCSRTEE, 2013) for a prescribed burn. Default values for the parameters in Eq. (5) are described in AUSNIR as emission factors from Hurst et al. (1996) $\left(\Sigma \mathrm{C}_{\text {emit }} / \mathrm{C}_{\text {fuel }}=0.9684\right), \mathrm{C}_{\text {fuel }}$ is $0.5, \mathrm{BEF}$ is 0.42 and the fuel load is $17.9 \mathrm{Mg} \mathrm{ha}^{-1}$.

\subsection{Uncertainty analysis of emission calculations}

We completed seven different Monte Carlo simulations for each site, in which input parameters were replaced by nor- mally distributed probability density functions (PDFs). Table 1 outlines for the seven different scenarios the equation used to do the calculations (Eqs. 4 or 5), the range of the values used for each input parameter (for each fuel fraction and site) and whether coarse woody debris was included in the calculations. Scenario 7 used the default fuel load applicable to these sites from the Australian National Greenhouse Accounts, National Inventory Report 2011 (DIICCSRTE, 2013). A priori analysis of the initial number of iterations for each Monte Carlo simulation needed to produce an analysis where the true mean of the distribution lies within $1 \%$ of the estimate were made before each simulation. The maximum estimated number of simulations for any one set of sites and scenario was 71233 . The true error of the estimated mean for each site and scenario was always less than $1 \%$. Results of the simulations are expressed as $95 \%$ uncertainty ranges defined by the 2.5 and 97.5 percentiles. The simulations were performed using MS Excel (Microsoft Corporation, Redmond, US)

\subsection{Statistics}

Linear mixed models (IBM SPSS Statistics, v. 21.0; IBM, Armonk, US) were used to analyse effects of fire on fuel (biomass) type, with site, plot and fuel type as subject variables and time as the repeated variable. Time, site and time $\times$ site interactions were used as fixed effects. Fuel loads for the different types of fuel (i.e. twigs, decomposing matter, near-surface live, leaf litter, CWD, understorey and overstorey), before and after burning, carbon content, $\Sigma \mathrm{C}_{\text {emit }} / \mathrm{C}_{\text {fuel }}$ and emission factors were analysed with linear mixed models where site, plot and fuel type were subject variables. Site, fuel type and site $\times$ fuel type interactions were used as fixed effects. The Bonferroni test was used for pairwise comparisons of the site and fuel type factors. Carbon content, $\Sigma \mathrm{C}_{\mathrm{emit}} / \mathrm{C}_{\text {fuel }}$ and the emission factors were arcsin transformed to meet assumptions of normality and homogeneity of variance.

\section{Results}

\subsection{Fuel load and carbon content}

Total fuel load before planned burning ranged from $61.7 \pm 15.3 \mathrm{Mg} \mathrm{ha}^{-1}$ (mean \pm standard deviation) at South Boundary to $111.3 \pm 26.2 \mathrm{Mgha}^{-1}$ at Upper Tambo but were not significantly different among sites (linear mixed model; $P=0.303$ ). There was 10 -fold more CWD than all other fuel types at all sites $(P<0.001$; Table 2$)$. Masses of all remaining fuel types at each site were similar (less than $\left.8 \mathrm{Mgha}^{-1} ; P=1.000\right)$ and there were no significant site $\times$ fuel type interactions $(P=0.692)$. After burning, total fuel loads at all sites were significantly reduced $(P<0.001)$ and ranged from $20.1 \pm 7.2 \mathrm{Mgha}^{-1}$ at Upper Tambo to 97.2 $\pm 24.7 \mathrm{Mg} \mathrm{ha}^{-1}$ at Oliver (Table 2). Reductions in fuel 
Table 1. Summary of parameters and range of values used to calculate emission estimates for seven different scenarios by Monte Carlo simulation. Max. to min. refers to the maximum and minimum values recorded for each fuel type and site. CWD is coarse woody debris. See text for further details of the equations used.

\begin{tabular}{lccccccc}
\hline Scenario & Calculation & \multicolumn{5}{c}{ Parameters } \\
\cline { 2 - 7 } & equation & $\begin{array}{c}\text { Carbon } \\
\text { content } \\
(\%)\end{array}$ & $\begin{array}{c}\text { Emission } \\
\text { factors } \\
\left(\mathrm{g} \mathrm{Cg} \mathrm{C}^{-1}\right)\end{array}$ & $\begin{array}{c}\text { Mass } \\
\text { loss } \\
\left(\mathrm{Mgha}^{-1}\right)\end{array}$ & $\begin{array}{c}\text { Pre-burn } \\
\text { fuel loads } \\
\left(\mathrm{Mgha}^{-1}\right)\end{array}$ & $\begin{array}{c}\text { Burning } \\
\text { efficiency } \\
\text { factor }\end{array}$ & $\begin{array}{c}\text { CWD } \\
\text { included? }\end{array}$ \\
\hline 1 & 4 & Max. to min. & Max. to min. & Max. to min. & - & - & Yes \\
2 & 4 & Max. to min. & Max. to min. & Max. to min. & - & - & No \\
3 & 4 & $0-100$ & $0-1$ & Max. to min. & - & - & Yes \\
4 & 4 & $0-100$ & $0-1$ & Max. to min. & - & No \\
5 & 5 & $0-100$ & $0-1$ & - & Max. to min. & $0-1$ & Yes \\
6 & 5 & $0-100$ & $0-1$ & - & Max. to min. & $0-1$ & No \\
7 & 5 & $0-100$ & $0-1$ & - & 17.9 & $0-1$ & No \\
\hline
\end{tabular}

Table 2. Fuel load and pre-burn carbon content of a range of fuel types measured before and after fire in four forest sites in East Gippsland, south-eastern Australia. Values are mean \pm standard deviation $(n=3)$.

\begin{tabular}{|c|c|c|c|c|c|c|}
\hline \multirow{3}{*}{ Fuel type } & \multicolumn{3}{|c|}{ Oliver } & \multicolumn{3}{|c|}{ Pettmans } \\
\hline & \multicolumn{2}{|c|}{ Fuel load $\left(\mathrm{Mgha}^{-1}\right)$} & \multirow{2}{*}{$\begin{array}{l}\text { Carbon content } \\
\text { (\% dry weight) } \\
\text { Pre-burn }\end{array}$} & \multicolumn{2}{|c|}{ Fuel load $\left(\mathrm{Mgha}^{-1}\right)$} & \multirow{2}{*}{$\begin{array}{l}\text { Carbon content } \\
\text { (\% dry weight) } \\
\text { Pre-burn }\end{array}$} \\
\hline & Pre-burn & Post-burn & & Pre-burn & Post-burn & \\
\hline Twigs & $7.75 \pm 1.65$ & $3.70 \pm 1.58$ & $49.67 \pm 0.15$ & $5.23 \pm 1.31$ & $0.01 \pm 0.01$ & $48.78 \pm 0.88$ \\
\hline Decomposing matter & $3.11 \pm 0.57$ & $2.03 \pm 2.01$ & $29.79 \pm 6.04$ & $5.69 \pm 1.36$ & $0.02 \pm 0.01$ & $23.87 \pm 7.05$ \\
\hline Ground layer & $3.31 \pm 1.57$ & $0.02 \pm 0.03$ & $46.68 \pm 0.08$ & $0.62 \pm 0.33$ & 0 & $46.74 \pm 1.36$ \\
\hline Leaf litter & $1.85 \pm 0.59$ & $1.25 \pm 0.17$ & $54.95 \pm 0.31$ & $2.80 \pm 0.29$ & $0.27 \pm 0.13$ & $52.35 \pm 1.92$ \\
\hline Coarse woody debris & $75.91 \pm 19.64$ & $76.43 \pm 21.73$ & $49.67 \pm 0.15$ & $61.14 \pm 55.33$ & $53.11 \pm 58.08$ & $48.78 \pm 0.88$ \\
\hline Understorey & $1.78 \pm 1.50$ & $1.69 \pm 1.48$ & $53.53 \pm 0.36$ & $0.80 \pm 0.54$ & $0.76 \pm 0.49$ & $53.53 \pm 0.36$ \\
\hline \multirow[t]{2}{*}{ Overstorey } & $14.87 \pm 4.32$ & $12.08 \pm 3.17$ & $54.95 \pm 0.31$ & $3.73 \pm 1.40$ & $3.38 \pm 1.80$ & $54.95 \pm 0.31$ \\
\hline & \multicolumn{3}{|c|}{ South Boundary } & \multicolumn{3}{|c|}{ Upper Tambo } \\
\hline Twigs & $5.32 \pm 0.67$ & $0.07 \pm 0.03$ & $49.59 \pm 0.42$ & $5.91 \pm 0.68$ & $0.06 \pm 0.02$ & $49.14 \pm 1.26$ \\
\hline Decomposing matter & $6.89 \pm 0.23$ & $0.05 \pm 0.02$ & $32.13 \pm 2.69$ & $5.94 \pm 1.05$ & $0.03 \pm 0.01$ & $35.42 \pm 2.06$ \\
\hline Ground layer & $0.33 \pm 0.18$ & 0 & $47.72 \pm 1.85$ & $0.11 \pm 0.06$ & 0 & $47.57 \pm 0.94$ \\
\hline Leaf litter & $4.25 \pm 0.82$ & $0.37 \pm 0.11$ & $53.55 \pm 2.45$ & $9.49 \pm 10.56$ & $0.30 \pm 0.18$ & $53.70 \pm 1.69$ \\
\hline Coarse woody debris & $41.66 \pm 16.39$ & $33.35 \pm 15.00$ & $49.59 \pm 0.42$ & $83.70 \pm 37.29$ & $14.56 \pm 5.99$ & $49.14 \pm 1.26$ \\
\hline Understorey & $0.52 \pm 0.37$ & $1.01 \pm 0.22$ & $53.53 \pm 0.36$ & $0.10 \pm 0.17$ & $0.29 \pm 0.49$ & $53.53 \pm 0.36$ \\
\hline Overstorey & $2.78 \pm 1.41$ & $2.12 \pm 0.91$ & $54.95 \pm 0.31$ & $6.07 \pm 1.95$ & $4.89 \pm 1.40$ & $54.95 \pm 0.31$ \\
\hline
\end{tabular}

load due to burning were not consistent, resulting in significant time $\times$ site $(P=0.025)$ and time $\times$ fuel type interactions $(P=0.003$; Table 2; Fig. 2$)$. Time $\times$ site interactions resulted mainly from an $80 \%$ reduction in total fuel load at Upper Tambo, but only a $10 \%$ reduction at Oliver (Fig. 2). Fuel loads were reduced by an average of $28 \%$ at Pettmans and $40 \%$ at South Boundary (Fig. 2). A significant time $\times$ fuel type interaction was expected given small reductions in CWD mass after burning compared to other fuel types ( $P=0.002$; Table 2; Fig. 2). Even so, there were significant differences in amounts of CWD burnt among sites. At Oliver, Pettmans and South Boundary, amounts of CWD biomass consumed were significantly less than at Upper Tambo $(P=0.017$; Table 2; Fig. 2$)$.
Twig mass (up to $8 \mathrm{Mg} \mathrm{ha}^{-1}$ pre-burn) was significantly reduced by burning $(P<0.001)$ with an average loss of close to $5 \mathrm{Mgha}^{-1}$. There were no time $\times$ site interactions ( $P=0.656)$ but the mass of twigs measured at Oliver was significantly greater than at Upper Tambo both before and after burning ( $P=0.05$; Table 2; Fig. 2). Burning significantly reduced the mass of decomposing matter at all sites (up to $7 \mathrm{Mg} \mathrm{ha}^{-1}$ pre-burn) by almost $5 \mathrm{Mg} \mathrm{ha}^{-1}(P<0.001)$. Reductions in mass were greater at Pettmans, South Boundary and Upper Tambo than at Oliver. Again, there was a significant time $\times$ site interaction $(P=0.007)$.

Fuel loads represented by the ground layer vegetation (up to $0.6 \mathrm{Mgha}^{-1}$ pre-burn for Pettmans, South Boundary and Upper Tambo) were significantly less after burning $(P=0.002$; Table 2; Fig. 2$)$. There were significant 
Table 3. Proportion of the fuel carbon burnt emitted into the atmosphere from different fuel types from forest sites in East Gippsland, south-eastern Australia. $C_{\text {emit }}$ is the total carbon emitted into the atmosphere through combustion and $C_{\text {fuel }}$ is the initial carbon content of fuel. Coarse woody debris was assumed to have the same values as twigs. Values are mean \pm standard deviation $(n=3)$.

\begin{tabular}{lcccc}
\hline Fuel type & Oliver & $\begin{array}{c}\text { Pettmans } \\
\Sigma C_{\text {emit }} / C_{\text {fuel }}\end{array}$ & South Boundary & Upper Tambo \\
\hline Twigs & $0.882 \pm 0.015$ & $0.819 \pm 0.043$ & $0.844 \pm 0.026$ & $0.857 \pm 0.060$ \\
Decomposing matter & $0.710 \pm 0.177$ & $0.558 \pm 0.342$ & $0.751 \pm 0.136$ & $0.632 \pm 0.090$ \\
Ground layer & $0.978 \pm 0.009$ & $0.960 \pm 0.017$ & $0.948 \pm 0.058$ & $0.986 \pm 0.009$ \\
Leaf litter & $0.957 \pm 0.013$ & $0.975 \pm 0.025$ & $0.956 \pm 0.035$ & $0.915 \pm 0.019$ \\
Understorey & $0.859 \pm 0.054$ & $0.859 \pm 0.054$ & $0.859 \pm 0.054$ & $0.859 \pm 0.054$ \\
Overstorey & $0.942 \pm 0.014$ & $0.942 \pm 0.014$ & $0.942 \pm 0.014$ & $0.942 \pm 0.014$ \\
\hline
\end{tabular}

site $\times$ time interactions $(P=0.004)$ as a consequence of substantially greater amounts of such vegetation at Oliver before burning $\left(3 \mathrm{Mg} \mathrm{ha}^{-1}\right)$ than any of the other sites. None or very little of this fuel type remained after burning. Fire strongly reduced the mass of leaf litter and there were no major differences among sites before and after burning (2-9 $\mathrm{Mg} \mathrm{ha}^{-1}$; $P=0.398$; Table 2).

Understorey biomass was not significantly different after burning compared to before burning at all sites $(P=0.392)$, but was significantly different among sites $(P=0.001)$. Understorey biomass at Oliver was significantly greater (nearly $2 \mathrm{Mg} \mathrm{ha}^{-1}$ pre-burn) than at any of the other sites before and after burning ( $P=0.001$ to 0.013 ). Overstorey biomass was significantly different among sites before (ranging from 6 to $15 \mathrm{Mg} \mathrm{ha}^{-1} ; P<0.001$ ) and after burning (ranging from 2 to $\left.12 \mathrm{Mg} \mathrm{ha}^{-1} ; P=0.009\right)$. There was no interaction between site and time $(P=0.167)$. Understorey fuel loads at all sites decreased after burning by a little more than $1 \mathrm{Mg} \mathrm{ha}^{-1}$.

Mean carbon contents of decomposing matter $(30 \pm 2 \%)$ were significantly less than of other fuel types at all sites (linear mixed model; $P<0.001$; Table 2). Carbon contents of all other fuel types were in a narrow range $(45-56 \%)$ resulting in significant site $\times$ fuel type interactions $(P=0.009$; Table 2).

\subsection{Emission factors}

Amounts of carbon lost to the atmosphere relative to amounts held in aboveground biomass (the so called "fuel carbon") were similar among the four sites (linear mixed model; $P=0.456 ; \Sigma \mathrm{C}_{\mathrm{emit}} / \mathrm{C}_{\text {fuel }}$; Table 3 ). For the four sites, the mean proportion of fuel carbon lost to the atmosphere was $86 \%$ with a $95 \%$ confidence interval range of $77-95 \%$. There were significant differences among different fuel types $(P<0.001) . \Sigma\left(\mathrm{C}_{\mathrm{emit}} / \mathrm{C}_{\text {fuel }}\right)$ was significantly less in decomposing matter compared to other fuels $(P<0.001$; Table 3$)$. Twigs, CWD and understorey biomass had statistically similar $\Sigma\left(\mathrm{C}_{\text {emit }} / \mathrm{C}_{\text {fuel }}\right)(P>0.05)$. These $\Sigma\left(\mathrm{C}_{\text {emit }} / \mathrm{C}_{\text {fuel }}\right)$ were all less than those for ground layer, overstorey and leaf litter $(P<0.04)$. The latter three fuel types had statistically similar $\Sigma\left(\mathrm{C}_{\mathrm{emit}} / \mathrm{C}_{\text {fuel }}\right)(P>0.05)$.
For the four sites, the mean proportion of carbon lost to the atmosphere in the form of $\mathrm{CO}_{2}$ was $71 \%$ with a range of 65 $80 \%$ (Table 4). In contrast, proportions of carbon lost to the atmosphere as $\mathrm{CO}$ were much smaller $(2-4 \%)$. Emission factors for $\mathrm{CO}_{2}$ were similar among the four sites $(P=0.456)$ albeit with significant differences among different fuel types $(P<0.001)$. Emission factors for $\mathrm{CO}_{2}$ ranged from 0.43 to $1.00 \mathrm{~g} \mathrm{Cg} \mathrm{C}^{-1}$ among the different fuel types. Twigs and leaf litter produced significantly smaller emission factors than decomposing matter and overstorey biomass $(P<0.05)$. Emission factors for ground layer and understorey biomass were similar to those for twigs and leaf litter. Emission factors for $\mathrm{CO}$ were dependent on site $\times$ fuel type interactions $(P=0.026$; Table 4). At South Boundary and Upper Tambo, emission factors for $\mathrm{CO}$ were greater for decomposing matter and ground layer fuels relative to the other types $(P<0.05$; Table 4). In contrast, at Oliver and Pettmans, decomposing material had greater emission factors for $\mathrm{CO}$ than other fuel types $(P<0.026$; Table 4$)$

Pooled emission factors for $\mathrm{CH}_{4}$, VOC and PM $\left(\Sigma\left(\mathrm{CH}_{4}\right.\right.$, VOC, PM); Table 4) were significantly different among sites $(P=0.002)$ and fuel types $(P<0.001)$. Emission factors for $\Sigma\left(\mathrm{CH}_{4}, \mathrm{VOC}, \mathrm{PM}\right)$ for fuel collected from Upper Tambo were significantly less than fuels of other sites $(P<0.049)$. As a consequence, the average proportion of carbon lost to the atmosphere as $\Sigma\left(\mathrm{CH}_{4}, \mathrm{VOC}, \mathrm{PM}\right)$ from the four sites ranged widely (13-23\%). Differences in emission factors among fuel types were due to lesser emission factors for decomposing matter relative to all other fuel types and greater emission factors for leaf litter relative to understorey and overstorey biomass $(P<0.017)$.

Carbon content of the different fuel types and ash (from the calorimeter) (Table S1 in the Supplement), initial bulk density and residual mass fractions (Table $\mathrm{S} 2$ in the Supplement), excess $\mathrm{CO} / \mathrm{CO}_{2}$ and excess $\Sigma\left(\mathrm{CH}_{4}, \mathrm{VOC}\right.$, $\mathrm{PM}) / \mathrm{CO}_{2}$ ratios (Table $\mathrm{S} 3$ in the Supplement) used to calculate the emission factors, on both a mass of compound released per unit of fuel mass burnt and on a carbon mass balance basis, can be found in the supplementary material.

\subsection{Emission estimates}

Results of the Monte Carlo simulations of estimated emissions from the four sites, using seven different calculation scenarios, are shown in Fig. 3. Scenario 1 produced symmetrically distributed estimates, with median estimates ranging from close to $20 \mathrm{MgCO}_{2} \mathrm{eha}^{-1}$ for Oliver to $139 \mathrm{Mg} \mathrm{CO}_{2} \mathrm{e} \mathrm{ha}^{-1}$ for Upper Tambo. If CWD was omitted (Scenario 2), distributions were narrower and median estimates were reduced. The reduction in the median estimate varied among sites; for Oliver the reduction was $3 \%$, Pettmans $34 \%$, South Boundary $38 \%$ and Upper Tambo $71 \%$.

Scenario 3 produced positively skewed distributions for all sites and reduced median estimates (by $40-54 \%$ from 
Table 4. Emissions factors for $\mathrm{CO}_{2}, \mathrm{CO}$ and pooled $\mathrm{CH}_{4}$, volatile organic compounds (VOC) and particulate matter (PM) for different fuel types from forest sites in East Gippsland, south-eastern Australia, that were combusted in a mass-loss calorimeter. Coarse woody debris was assumed to have the same values as twigs. Values are mean \pm standard deviation $(n=3)$.

\begin{tabular}{|c|c|c|c|c|c|c|}
\hline \multirow[b]{2}{*}{ Fuel type } & \multicolumn{3}{|c|}{$\begin{array}{c}\text { Oliver } \\
\text { Emission factor }\left[\mathrm{gC} \mathrm{g} \mathrm{C}^{-1}\right]\end{array}$} & \multicolumn{3}{|c|}{$\begin{array}{c}\text { Pettmans } \\
\text { Emission factor }\left[\mathrm{gC} \mathrm{g} \mathrm{C}^{-1}\right]\end{array}$} \\
\hline & $\mathrm{CO}_{2}$ & $\mathrm{CO}$ & $\begin{array}{l}\Sigma \mathrm{CH}_{4}, \mathrm{NMHC}, \\
\mathrm{PM}\end{array}$ & $\mathrm{CO}_{2}$ & $\mathrm{CO}$ & $\begin{array}{l}\Sigma \mathrm{CH}_{4}, \mathrm{NMHC}, \\
\mathrm{PM}\end{array}$ \\
\hline Twigs & $0.59 \pm 0.03$ & $0.02 \pm 0.01$ & $0.28 \pm 0.05$ & $0.58 \pm 0.03$ & $0.02 \pm 0.01$ & $0.23 \pm 0.04$ \\
\hline Decomposing matter & $0.87 \pm 0.13$ & $0.06 \pm 0.02$ & $0.05 \pm 0.08$ & $1.00 \pm 0.08$ & $0.06 \pm 0.01$ & 0 \\
\hline Ground layer & $0.62 \pm 0.02$ & $0.03 \pm 0.01$ & $0.35 \pm 0.02$ & $0.58 \pm 0.04$ & $0.03 \pm 0.01$ & $0.37 \pm 0.05$ \\
\hline Leaf litter & $0.53 \pm 0.03$ & $0.02 \pm 0.01$ & $0.42 \pm 0.02$ & $0.56 \pm 0.07$ & $0.03 \pm 0.01$ & $0.40 \pm 0.06$ \\
\hline Coarse woody debris & $0.59 \pm 0.03$ & $0.02 \pm 0.01$ & $0.28 \pm 0.05$ & $0.58 \pm 0.03$ & $0.02 \pm 0.01$ & $0.23 \pm 0.04$ \\
\hline Understorey & $0.66 \pm 0.19$ & $0.02 \pm 0.02$ & $0.20 \pm 0.15$ & $0.66 \pm 0.19$ & $0.02 \pm 0.02$ & $0.20 \pm 0.15$ \\
\hline \multirow[t]{2}{*}{ Overstorey } & $0.79 \pm 0.06$ & $0.03 \pm 0.01$ & $0.14 \pm 0.06$ & $0.79 \pm 0.06$ & $0.03 \pm 0.01$ & $0.14 \pm 0.06$ \\
\hline & \multicolumn{3}{|c|}{ South Boundary } & \multicolumn{3}{|c|}{ Upper Tambo } \\
\hline Twigs & $0.47 \pm 0.02$ & $0.02 \pm 0.01$ & $0.36 \pm 0.02$ & $0.70 \pm 0.06$ & $0.02 \pm 0.01$ & $0.15 \pm 0.07$ \\
\hline Decomposing matter & $0.68 \pm 0.05$ & $0.03 \pm 0.01$ & $0.07 \pm 0.08$ & $0.89 \pm 0.17$ & $0.05 \pm 0.01$ & 0 \\
\hline Ground layer & $0.69 \pm 0.18$ & $0.04 \pm 0.01$ & $0.23 \pm 0.12$ & $0.74 \pm 0.03$ & $0.05 \pm 0.01$ & $0.22 \pm 0.03$ \\
\hline Leaf litter & $0.65 \pm 0.07$ & $0.02 \pm 0.01$ & $0.29 \pm 0.10$ & $0.68 \pm 0.04$ & $0.03 \pm 0.01$ & $0.22 \pm 0.04$ \\
\hline Coarse woody debris & $0.59 \pm 0.03$ & $0.02 \pm 0.01$ & $0.28 \pm 0.05$ & $0.58 \pm 0.03$ & $0.02 \pm 0.01$ & $0.23 \pm 0.04$ \\
\hline Understorey & $0.66 \pm 0.19$ & $0.02 \pm 0.02$ & $0.20 \pm 0.15$ & $0.66 \pm 0.19$ & $0.02 \pm 0.02$ & $0.20 \pm 0.15$ \\
\hline Overstorey & $0.79 \pm 0.06$ & $0.03 \pm 0.01$ & $0.14 \pm 0.06$ & $0.79 \pm 0.06$ & $0.03 \pm 0.01$ & $0.14 \pm 0.06$ \\
\hline
\end{tabular}

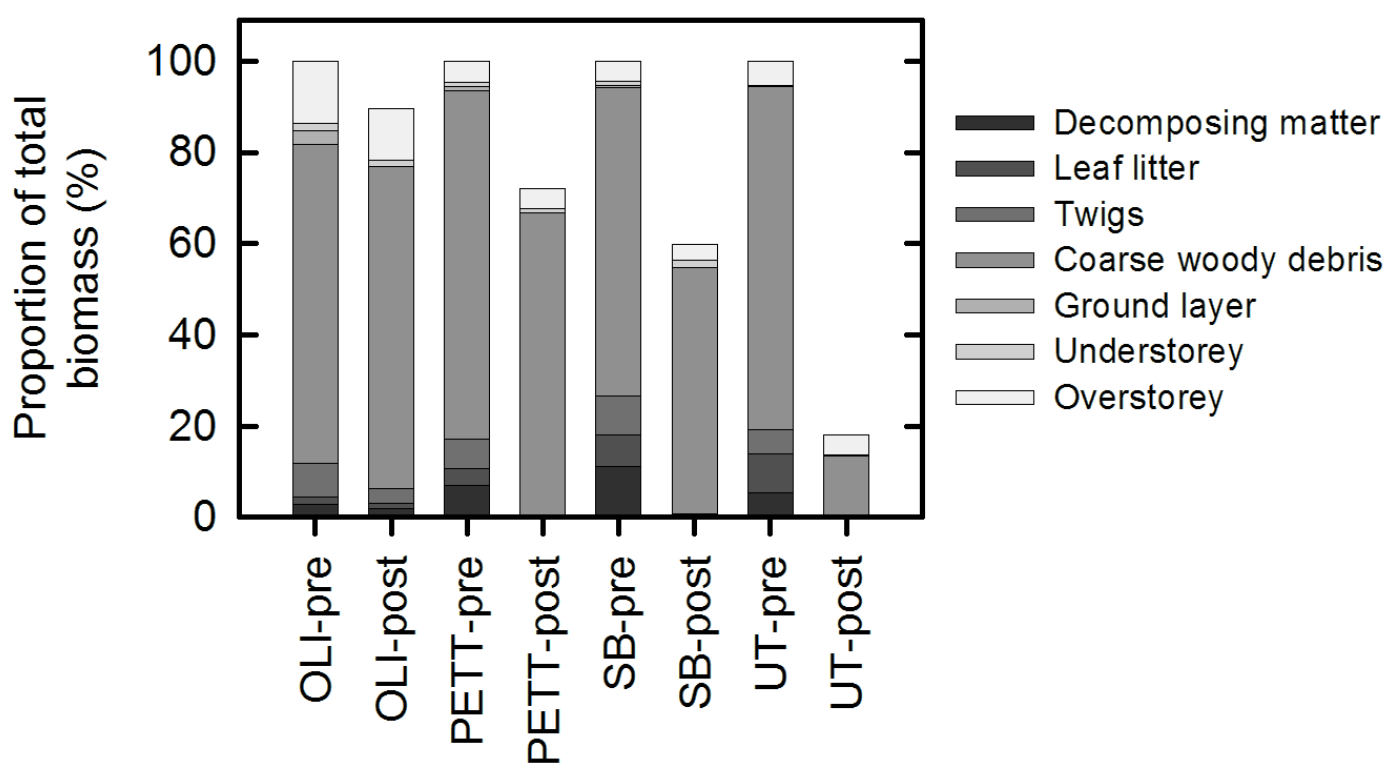

Figure 2. Proportion of the total biomass for each fuel type, at each site, before and after planned burning. The sites are Oliver (OLI), Pettmans (PETT), South Boundary (SB) and Upper Tambo (UT). Each section of each bar represents the mean proportion measured from three plots within each site. "Pre" and "post" refer to measurements made before and after the planned burn.

Scenario 1). Outputs of Scenario 4 (Scenario 3 excluding CWD) were similarly positively skewed, but more narrowly distributed. Relative to Scenario 1, excluding CWD lowered median estimated emissions by $53-83 \%$. Relative to Scenario 3, such exclusion lowered median estimates by 4-69\%. Scenario 5 produced the most positively skewed distributions for Oliver, Pettmans and South Boundary (Fig. 3). Consequently, the median estimate for Oliver was $90 \%$ greater than that of Scenario 1. Median estimates for other sites were between 16 and $76 \%$ less. When the same calculation method (Scenario 5) was applied, but excluding CWD data (Scenario 6), the distribution was still positively skewed but with 


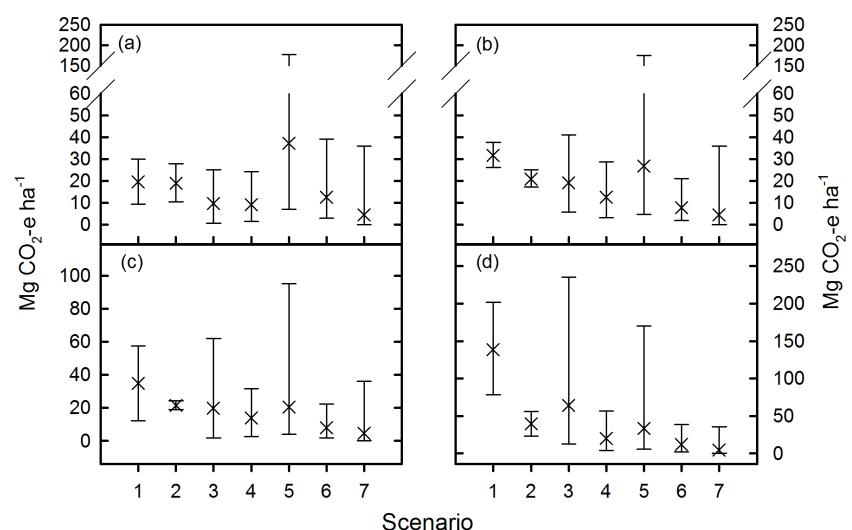

Figure 3. Estimates of equivalent $\mathrm{CO}_{2}$ emissions from four forest sites in East Gippsland, south-eastern Australia using Monte Carlo simulations of seven different scenarios. Sites are (a) Oliver, (b) Pettmans, (c) South Boundary and (d) Upper Tambo. See Table 1 for description of the seven scenarios. Crosses represent the median emission as determined by the Monte Carlo simulations ( $n \leq 71233)$. The error bars represent the $95 \%$ confidence intervals of the Monte Carlo simulations.

a much narrower range (Fig. 3). The omission of CWD data in Scenario 6 resulted in a median estimate (relative to Scenario 1) reduced by between 36 and $91 \%$ across all sites.

Simulations for sites using default fuel load, carbon content and emission factors from the Australian National Greenhouse Accounts, National Inventory Report 2011 (AUSNIR; DIICCSRTE, 2013; hereafter referred to as Scenario 7) were highly positively skewed, with a median estimate of $4.5 \mathrm{Mg} \mathrm{ha}^{-1}$. This is some $77-97 \%$ less than median estimates for the four sites from Scenario 1 . The $95 \%$ confidence range of Scenario 7 ranged from $0.05 \mathrm{Mg} \mathrm{ha}^{-1}$ to more than $35 \mathrm{Mgha}^{-1}$ with a mean value of close to $8 \mathrm{Mgha}^{-1}$. Using default values in AUSNIR, estimated mean total emission across all sites was $13.3 \mathrm{Mg} \mathrm{ha}^{-1}$. This is in the upper quartile of estimates for Scenario 7.

Based on Scenario 7, the probability that emissions are less than the median calculated using Scenario 1 was $88 \%$ for Oliver, $96 \%$ for Pettmans and $97 \%$ for South Boundary. For Upper Tambo, emission estimates based on Scenario 1 were outside the range of those calculated under Scenario 7.

\section{Discussion}

There were large differences in mass (biomass plus litter) lost among the four sites due to prescribed fire. These differences were due to the differing abundances, and consumption during fire, of the different fuel types. Given planned burning aims especially to reduce the loads of fine fuels (e.g. twigs, decomposing matter, ground layer vegetation and leaf litter), the fires studied here achieved this goal with only small changes in understorey and overstorey biomass. Losses of mass from CWD accounted for much of the vari- ation among sites, especially when considered in proportion to losses from finer fuels. When expressed in terms of carbon content, losses of carbon from CWD at Pettmans and South Boundary (18-24\%) were greater than from Eucalyptus obliqua forests of south-east Australia (Volkova and Weston, 2013), but consistent with the model results of Hollis et al. (2011). In contrast, fine fuel and CWD accounted for $79 \%$ of the C lost at the Upper Tambo site. The site east of Orbost (Oliver) lost the least amount of mass (and C), retaining most of its fine fuels and showing no appreciable change in CWD. Estimation of fuel load is a major source of uncertainty in any estimation of potential or actual fire emissions, and the large variability in burning efficiency across the sites used in this study is consistent with variability described by Stropiana et al. (2010) and Urbanski et al. (2011).

Across the four sites, the mean proportion of fuel carbon lost to the atmosphere relative to the total amount of carbon $\left(\Sigma \mathrm{C}_{\mathrm{emit}} / \mathrm{C}_{\text {fuel }}\right)$ was $86 \%$. This is less than the $97 \%$ suggested by Hurst et al. (1996) for the one planned burn they measured in a south-east Australian forest. However, a direct comparison of this study with the Hurst et al. (1996) study cannot be made due to the significantly different methodological approaches taken that they may bias either study. These methodological differences include factors such as the measurement of aggregated emissions from naturally structured fuels taken using an aircraft compared to individual fuel components measured at a very small scale in the laboratory; neither study measures the same range of compounds. Indeed, these methodological differences also prevent direct comparison of emission factors, not just with Hurst et al. (1996) but also the recent work of Paton-Walsh et al. (2014), who made ground-based emission measurements from planned fires in temperate south-east Australian fires. There are large variabilities in emission factors for certain compounds among different ecosystems (see reviews by Andreae and Merlet, 2001 and Akagi et al., 2011). This demonstrates the need for more comprehensive emissions measurements for specific ecosystems and regions, including southeast Australian forests. If these measurements are conducted in a manner similar to those for the south-eastern and southwestern US (e.g. Yokelson et al., 2013), field and laboratory measurements may be reconciled.

Monte Carlo simulations clearly demonstrated the significance of availability of data to accurate calculations of likely emissions. If only fuel load (before and after burning) is known and default values from AUSNIR are used, estimated emissions could vary from true emissions by as much as $100 \%$. One characteristic common across all simulations was that when data for CWD is included, the range of emissions increased strongly as a result of large variation in mass of CWD among sites. In addition, there was wide variation among sites in consumption of CWD during prescribed fires. Emissions estimated using Scenarios 1, 2, 3 and 4, where fuel loads were known before and after burning, had greatly reduced variance. Distributions of estimated emissions were 
more positively skewed as the amount of data available declined. In other words, the probability of an estimate being in the low portion of the distribution is greatly increased, in addition to the diminished probability that the estimate matches the true emission. This is amply demonstrated by the distribution of estimates calculated using Scenario 7 (AUSNIR default values), which encompassed the median emissions estimate of Scenario 1 for three of the four sites. There was, at most, only $12 \%$ probability of matching values. For the fourth site, Scenario 7 could not produce a distribution that overlapped with that calculated using Scenario 1.

This study has shown that even within a single, welldefined vegetation type, there is wide variability in emissions principally because of different burning efficiencies among sites and fuel types. In order to improve both the accuracy and precision of estimated emissions from planned burning, the use of a single efficiency factor, as described in AUSNIR, is clearly insufficient. The methodology used to predict emissions from savanna and grassland, where burning efficiencies are described as a function of fuel type and fire severity (Russell-Smith et al., 2009), is only effective if fuel loads are accurately known (Stropiana et al., 2010; Urbanski et al., 2011). Spatial variability in fuel loads (Burgan et al., 1998; Keane et al., 2001) and the spatiotemporal variability in fuel conditions (Clinton et al., 2006) mitigate such a scenario. We have shown that in addition to the mass of different fuel types, their carbon content plays a significant role in potential emissions. The Australian National Greenhouse Gas Inventory Report 2011 (DIICCSRTEE, 2013) assumes a $50 \%$ default value for carbon content of forest fuels. Fuel types in this study, with the exception of decomposing matter, had carbon contents ranging between $45 \%$ and $56 \%$, mostly close to the default value. However decomposing matter had a much lower C content (average 30\%). Combustion of fuels with low carbon contents could lead to overestimation of carbon loss. Considerable improvements in emissions estimates from temperate forests in south-eastern Australia could be made if a greater number of emission factors were available for different fuel types. This would eliminate current reliance on site-aggregated values and would aid in the development of predictive models for emission factors, particularly if different combustion conditions such as fuel moisture content, fuel load, fuel arrangement and fire intensity could be incorporated (Yokelson et al., 1999; Andreae and Merlet, 2001; Possell and Bell, 2013). Field studies are still required to verify laboratory determined emission factors.

\section{Summary}

Planned fires in a temperate Eucalyptus forest in south-east Australia released between 20 to $139 \mathrm{MgCO}_{2} \mathrm{eha}^{-1}$. Variability in the range of emissions was a consequence of different burning efficiencies among investigated fuel types, with greater emissions when appreciable amounts of CWD were burnt. Simulation of emissions showed that as the amount of information available to calculate emissions is reduced, the probability of estimating true emissions greatly diminishes. Ideally, measurement of fuel load and carbon content of different fuel types should be made before and after fire. In conjunction with emission factors for a greater range of fuel types and conditions, our ability to estimate of carbon loss from forests via prescribed burns would be greatly improved and would provide invaluable data on carbon apportionment for the calibration of fuel models.

\section{The Supplement related to this article is available online at doi:10.5194/bg-12-257-2015-supplement.}

Acknowledgements. This project was funded by a Linkage Grant from the Australian Research Council (Jenkins) and the Bushfire Cooperative Research Centre (Possell). It was conducted in conjunction with the Victorian Department of Environment and Primary Industries (DEPI). We thank Jaymie Norris (DEPI) and operations staff from the Orbost district office, particularly Greg McCarthy, Dean Kleinitz, Grant Tucker and Michael Ryan. We thank Peter Perry for assisting with site selection and implementing field protocols. We also thank Felipe Aires, Cristina Aponte, Tom Fairman, Simon Murphy, Cheryl Poon and Rob Law for assistance in the field and Cheryl Poon for assistance in preparing Fig. 1.

Edited by: E. Pendall

\section{References}

Adams, M. A.: Mega-fires, tipping points and ecosystem services: Managing forests and woodlands in an uncertain future, Forest Ecol. Manag., 294, 250-261, doi:10.1016/j.foreco.2012.11.039, 2013.

Akagi, S. K., Yokelson, R. J., Wiedinmyer, C., Alvarado, M. J., Reid, J. S., Karl, T., Crounse, J. D., and Wennberg, P. O.: Emission factors for open and domestic biomass burning for use in atmospheric models, Atmos. Chem. Phys., 11, 4039-4072, doi:10.5194/acp-11-4039-2011, 2011.

Andreae, M. O. and Merlet, P.: Emission of trace gases and aerosols from biomass burning, Global Biogeochem. Cy., 15, 955-966, 2001.

Bennett, L. T., Aponte, C., Tolhurst, K. G., Low, M., and Baker, T. G.: Decreases in standing tree-based carbon stocks associated with repeated prescribed fires in a temperate mixedspecies eucalypt forest, Forest Ecol. Manag., 306, 243-255, doi:10.1016/j.foreco.2013.06.036, 2013.

Bi, H. Q., Turner, J., and Lambert, M. J.: Additive biomass equations for native eucalypt forest trees of temperate Australia, Trees-Struct. Funct., 18, 467-479, doi:10.1007/s00468004-0333-z, 2004. 
Bradstock, R. A.: A biogeographic model of fire regimes in Australia: current and future implications, Global Ecol. Biogeogr., 19, 145-158, doi:10.1111/j.1466-8238.2009.00512.x, 2010.

Burgan, R. E., Klaver, R. W., and Klaver, J. M.: Fuel models and fire potential from satellite and surface observations, Int. J. Wildland Fire, 8, 159-170, doi:10.1071/wf9980159, 1998.

Clinton, N. E., Gong, P., and Scott, K.: Quantification of pollutants emitted from very large wildland fires in Southern California, USA, Atmos. Environ., 40, 3686-3695, doi:10.1016/j.atmosenv.2006.02.016, 2006.

DIICCSRTE.: Australian National Greenhouse Accounts, National Inventory Report 2011, Department of Industry, Innovation Climate Change, Science, Research and Tertiary Education, Canberra, 154 pp., 2013.

Glatthor, N., Höpfner, M., Semeniuk, K., Lupu, A., Palmer, P. I., McConnell, J. C., Kaminski, J. W., von Clarmann, T., Stiller, G. P., Funke, B., Kellmann, S., Linden, A., and Wiegele, A.: The Australian bushfires of February 2009: MIPAS observations and GEM-AQ model results, Atmos. Chem. Phys., 13, 1637-1658, doi:10.5194/acp-13-1637-2013, 2013.

Gould, J. S., McCaw, W. L., and Cheney, N. P.: Quantifying fine fuel dynamics and structure in dry eucalypt forest (Eucalyptus marginata) in Western Australia for fire management, For. Ecol. Manage., 262, 531-546, doi:10.1016/j.foreco.2011.04.022, 2011

Haverd, V., Raupach, M. R., Briggs, P. R., J. G. Canadell., Davis, S. J., Law, R. M., Meyer, C. P., Peters, G. P., Pickett-Heaps, C., and Sherman, B.: The Australian terrestrial carbon budget, Biogeosciences, 10, 851-869, doi:10.5194/bg-10-851-2013, 2013.

Hendrickx, M., Willman, C. E., Magart, A. P. M., and VandenBerg, A. H. M.: Orbost and part of Hartland 1:50000 geological map, Geological Survey of Victoria 1v Map, 1996.

Hollis, J. J., Matthews, S., Anderson, W. R., Cruz, M. G., and Burrows, N. D.: Behind the flaming zone: Predicting woody fuel consumption in eucalypt forest fires in southern Australia, Forest Ecol. Manag., 261, 2049-2067, doi:10.1016/j.foreco.2011.02.031, 2011.

Hurst, D. F., Griffith, D. W. T., Carras, J. N., Williams, D. J., and Fraser, P. J.: Measurements of trace gases emitted by Australian savanna fires during the 1990 dry season, J. Atmos. Chem., 18, 33-56, 1994a.

Hurst, D. F., Griffith, D. W. T., and Cook, G. D.: Trace gas emissions from biomass burning in tropical Australian savannas, J. Geophys. Res.-Atmos., 99, 16441-16456, 1994b.

Hurst, D. F., Griffith, D. W. T., and Cook, G. D.: Trace-gas emissions from biomass burning in Australia, in: Biomass Burning and Global Change, edited by: Levine, J. S., The MIT Press, Massachusetts, 787-794, 1996.

Ilic, J., Boland, D., McDonald, M., Downes, G., and Blakemore, P.: Woody density phase 1 - state of knowledge, National Carbon Accounting System Technical Report, Vol 18., Australian Greenhouse Office, Canberra , 2000.

Keane, R. E., Burgan, R., and van Wagtendonk, J.: Mapping wildland fuels for fire management across multiple scales: Integrating remote sensing, GIS, and biophysical modeling, Int. J. Wildland Fire, 10, 301-319, doi:10.1071/wf01028, 2001.

Langmann, B., Duncan, B., Textor, C., Trentmann, J., and van der Werf, G. R.: Vegetation fire emissions and their impact on air pollution and climate, Atmos. Environ., 43, 107-116, doi:10.1016/j.atmosenv.2008.09.047, 2009.

Loudermilk, E. L., Hiers, J. K., O’Brien, J. J., Mitchell, R. J., Singhania, A., Fernandez, J. C., Cropper, W. P., and Slatton, K. C.: Ground-based LIDAR: a novel approach to quantify finescale fuelbed characteristics, Int. J. Wildland Fire, 18, 676-685, doi:10.1071/wf07138, 2009.

McCaw, L.: Managing forest fuels using prescribed fire - a perspective from southern Australia, Forest Ecol. Manag., 294, 217-224, 2013.

Meyer, C. P., Cook, G. D., Reisen, F., Smith, T. E. L., Tattaris, M., Russell-Smith, J., Maier, S. W., Yates, C. P., and Wooster, M. J.: Direct measurements of the seasonality of emission factors from savanna fires in northern Australia, J. Geophys. Res.Atmos., 117, doi:10.1029/2012jd017671, 2012.

Paton-Walsh, C., Jones, N., Wilson, S., Meier, A., Deutscher, N., Griffith, D., Mitchell, R., and Campbell, S.: Trace gas emissions from biomass burning inferred from aerosol optical depth, Geophys. Res. Lett., 31, L05116, doi:10.1029/2003GL018973, 2004.

Paton-Walsh, C., Jones, N. B., Wilson, S. R., Haverd, V., Meier, A., Griffith, D. W. T., and Rinsland, C. P.: Measurements of trace gas emissions from Australian forest fires and correlations with coincident measurements of aerosol optical depth, J. Geophys. Res.-Atmos., 110, D24305, doi:10.1029/2005jd006202, 2005.

Paton-Walsh, C., Deutscher, N. M., Griffith, D. W. T., Forgan, B. W., Wilson, S. R., Jones, N. B., and Edwards, D. P.: Trace gas emissions from savanna fires in northern Australia, J. Geophys. Res.-Atmos., 115, D16314, doi:10.1029/2009jd013309, 2010.

Paton-Walsh, C., Smith, T. E. L., Young, E. L., Griffith, D. W. T., and Guérette, É.-A.: New emission factors for Australian vegetation fires measured using open-path Fourier transform infrared spectroscopy - Part 1: Methods and Australian temperate forest fires, Atmos. Chem. Phys., 14, 11313-11333, doi:10.5194/acp14-11313-2014, 2014.

Penman, T. D., Kavanagh, R. P., Binns, D. L., and Melick, D. R.:Patchiness of prescribed burns in dry sclerophyll eucalypt forests in south-eastern Australia. Forest Ecol. Manag., 252, 24 32, 2007

Possell, M. and Bell, T. L.: The influence of fuel moisture content on the combustion of Eucalyptus foliage, Int. J. Wildland Fire, 22, 343-352, doi:10.1071/WF12077, 2013.

Radke, L., Hegg, D., Lyons, J., Brock, C., Hobbs, P., Weiss, R., and Rasmussen, R.: Airborne measurements on smokes from biomass burning, in: Aerosols and Climate, edited by: Hobbs, P., McCormick, M., and Deepak, A., Hampton, 411-422, 1988.

Russell-Smith, J., Yates, C. P., Whitehead, P. J., Smith, R., Craig, R., Allan, G. E., Thackway, R., Frakes, I., Cridland, S., Meyer, M. C. P., and Gill, M.: Bushfires "down under": patterns and implications of contemporary Australian landscape burning, Int. J. Wildland Fire, 16, 361-377, doi:10.1071/wf07018, 2007.

Russell-Smith, J., Murphy, B. P., Meyer, C. P., Cook, G. D., Maier, S., Edwards, A. C., Schatz, J., and Brocklehurst, P.: Improving estimates of savanna burning emissions for greenhouse accounting in northern Australia: limitations, challenges, applications, Int. J. Wildland Fire, 18, 1-18, doi:10.1071/wf08009, 2009.

Seiler, W. and Crutzen, P. J.: Estimates of gross and net fluxes of carbon between the biosphere and the atmosphere from biomass burning, Clim. Change, 2, 207-247, doi:10.1007/bf00137988, 1980. 
Stroppiana, D., Brivio, P. A., Grégoire, J.-M., Liousse, C., G uillaume, B., Granier, C., Mieville, A., Chin, M., and Pétron, G.: Comparison of global inventories of $\mathrm{CO}$ emissions from biomass burning derived from remotely sensed data, Atmos. Chem. Phys., 10, 12173-12189, doi:10.5194/acp-10-12173-2010, 2010.

Urbanski, S. P., Hao, W. M., and Baker, S.: Chemical composition of wildland fire emissions, in: Wildland Fires and Air Pollution, edited by: Bytnerowicz, A., Arbaugh, M. J., Riebau, A. R., and Andersen, C., Developments in Environmental Science, 79-107, 2009.

Urbanski, S. P., Hao, W. M., and Nordgren, B.: The wildland fire emission inventory: western United States emission estimates and an evaluation of uncertainty, Atmos. Chem. Phys., 11, 12973-13000, doi:10.5194/acp-11-12973-2011, 2011.

VandenBerg, A. H. M., Hendrickx, M. A., Willman, C. E., Magart, A. P. M., Oranskaia, A., Rooney, S., and White, A. J. R.: The geology and prospectivity of the Orbost 1:100000 map area, Eastern Victoria, Victorian Initiative for Minerals and Petroleum Report, 25, 158 pp., 1996.

van der Werf, G. R., Randerson, J. T., Giglio, L., Collatz, G. J., Mu, M., Kasibhatla, P. S., Morton, D. C., DeFries, R. S., Jin, Y., and van Leeuwen, T. T.: Global fire emissions and the contribution of deforestation, savanna, forest, agricultural, and peat fires (19972009), Atmos. Chem. Phys., 10, 11707-11735, doi:10.5194/acp10-11707-2010, 2010.

van Wagner, C.: The line intersect method in forest fuel sampling, Forest. Sci., 10, 267-276, 1968.
Victoria Department of Sustainability and Environment.: Vegetation Quality Assessment Manual - Guidelines for Applying the Habitat Hectares Scoring Method Version 1.3., Victorian Government Department of Sustainability and Environment, Melbourne, 46 pp., 2004.

Volkova, L. and Weston, C.: Redistribution and emission of forest carbon by planned burning in Eucalyptus obliqua (L. Herit.) forest of south-eastern Australia, Forest Ecol. Manag., 304, 383390, doi:10.1016/j.foreco.2013.05.019, 2013.

Yokelson, R. J., Goode, J. G., Ward, D. E., Susott, R. A., Babbitt, R. E., Wade, D. D., Bertschi, I., Griffith, D. W. T., and Hao, W. M.: Emissions of formaldehyde, acetic acid, methanol, and other trace gases from biomass fires in North Carolina measured by airborne Fourier transform infrared spectroscopy, J. Geophys. Res.Atmos., 104, 30109-30125, doi:10.1029/1999jd900817, 1999.

Yokelson, R. J., Burling, I. R., Gilman, J. B., Warneke, C., Stockwell, C. E., de Gouw, J., Akagi, S. K., Urbanski, S. P., Veres, P., Roberts, J. M., Kuster, W. C., Reardon, J., Griffith, D. W. T., Johnson, T. J., Hosseini, S., Miller, J. W., Cocker III, D. R., Jung, H., and Weise, D. R.: Coupling field and laboratory measurements to estimate the emission factors of identified and unidentified trace gases for prescribed fires, Atmos. Chem. Phys., 13, 89-116, doi:10.5194/acp-13-89-2013, 2013.

Young, E. and Paton-Walsh, C.: Emission ratios of the tropospheric ozone precursors nitrogen dioxide and formaldehyde from Australia's Black Saturday fires, Atmosphere, 2, 617-632, doi:10.3390/atmos2040617, 2011. 